TITLE:

\title{
Social cohesion and health in old age: a study in southern Taiwan( Abstract_要旨 )
}

\section{$\operatorname{AUTHOR}(\mathrm{S})$ :}

Chen, Wen Ling

\section{CITATION:}

Chen, Wen Ling. Social cohesion and health in old age: a study in southern Taiwan. 京都 大学, 2015, 博士(社会健康医学)

ISSUE DATE:

2015-09-24

URL:

https://doi.org/10.14989/doctor.k19276

RIGHT: 
Social cohesion and health in old age: a study in southern Taiwan

題目

\section{(論文内容の要旨)}

Previous studies have found that social cohesion and trust (SCT) were associated with psychological well-being and physical health. Although previous studies show that SCT is highly associated with psychological and physical health, only few study has examined the association between social cohesion and health in Asian countries, where cohesive social networks embody more cultural value than individualism, which is more common in Western countries. The aim of this study is to investigate the associations between SCT and mental and physical health among community-dwelling elderly in a town in southern Taiwan, with a particular focus on comprehensive geriatric functions (CGA) such as quantitative subjective quality of life (QOL), depression, activities of daily living (ADL), and health behaviors.

The study population consisted of 149 community-dwelling elderly aged 65 years and older (68 men, 81 women; mean age, 75.4 6.1 years) residing in the town of Dashe, Tainan City, Taiwan, who had agreed to undergo the Comprehensive Geriatric Assessment (CGA) and had completed applicable portions in 2012. The total population of community-dwelling elderly aged 65 years and older in Dashe was 548 (10.9\% of the total population of 5003 people in 2012). Activities of daily living (ADL), SCT, depression, subjective quality of life (QOL), current medical status, past medical history, and health behaviors were assessed in face-to-face interviews. Objective neurobehavioral functions were assessed using the Timed Up \& Go (TUG) test, functional reach test, and handgrip test.

Mean SCT score was 19.9 \pm 2.7 for the entire study population, with mean SCT scores in males and female of 20.0 \pm 2.9 and 19.9 \pm 2.6 , respectively. There is no significant difference in SCT scores between those with and without health behaviors or other medical issues, except for a significant difference between those with and without past history of stroke. Scores for ADL and Geriatric Depression Scale (GDS) were significantly correlated with SCT, and SCT was significantly correlated with all subjective QOL items. In addition, a strong correlation was observed between SCT and relationship with friends. SCT $\geqq 20$ was not significantly associated with subjective sense of health (median $\geqq 68$ ) with the confounding factor of GDS $\geqq 5$ (OR: 0.29 vs. GDS $<5, P=0.001$ ) but associated with subjective happiness (OR: 2.54 vs. SCT $<20, P=0.009$ ) independently of GDS, ADL, age and sex, as analyzed by multivariate logistic regression.
The present study showed that SCT is an important factor that is associated with self-rated health and happiness independently of ADL, age, and sex in a community in Taiwan. When assessing geriatric psychological function, SCT should be more heavily considered, given its association with self-rated health and happiness, depression, and physical function.

\section{(論文審査の結果の要旨 $)$}

地域の信頼関係とつながり（以下：SCT）は、心理的状態や健康と関連することが欧米 等で報告されているが、アジア諸国における報告は少ない。本研究の目的は、南台湾の地 域在住高齢者を対象とし、老年医学的総合機能評価（Comprehensive Geriatric

Assessment:CGA）を用いて、SCT と心理的状態、健康度との関連を明らかにすることである。 2012 年、台湾・台南市 D 町地域在住高齢者 149 名（男性 68 名、女性 81 名、平均年齢 75.4 歳）を対象として、SCT と CGA との関連を検討した。CGA としては、基本的日常生活 機能 (ADL)、うつ状態の有無、主観的 Quality of life(QOL)、服薬状況、既往歴、神経行動機 能（TimedUP\&GO、ファンクショナルリーチ、握力）を評価した。

SCT と脳卒中以外の既往歷、現病歷、神経行動機能との関連は認めなかったが、SCT は ADL、GDS、QOL 5 項目とは有意な関連がみられた。SCT 值を 20 以上と 20 未満で2 群に分け て多変量ロジスティック回帰分析を行うと、SCT 20 は、主観的健康感にはGDS と交絡が みられたが、主観的幸福感とは、GDS、ADL、年齢と性別で調整しても有意な関連が認めら れた SCT は主観的健康感、主観的幸福感、うつ状態、ADL と関連があり、高齢者の健康を 考えるうえで、SCT にもっと注意を払う必要がある。

以上の研究は、地域在住高齢者の健康度と社会の信頼関係とつながりの解明に貢献 し、老年医学に寄与するところが多い。

したがって、本論文は博士 (社会健康医学) の学位論文として価值あるものと認める。 なお、本学位授与申請者は、平成 27 年 7 月 23 日実施の論文内容とそれに関連した 試問を受け、合格と認められたものである。 


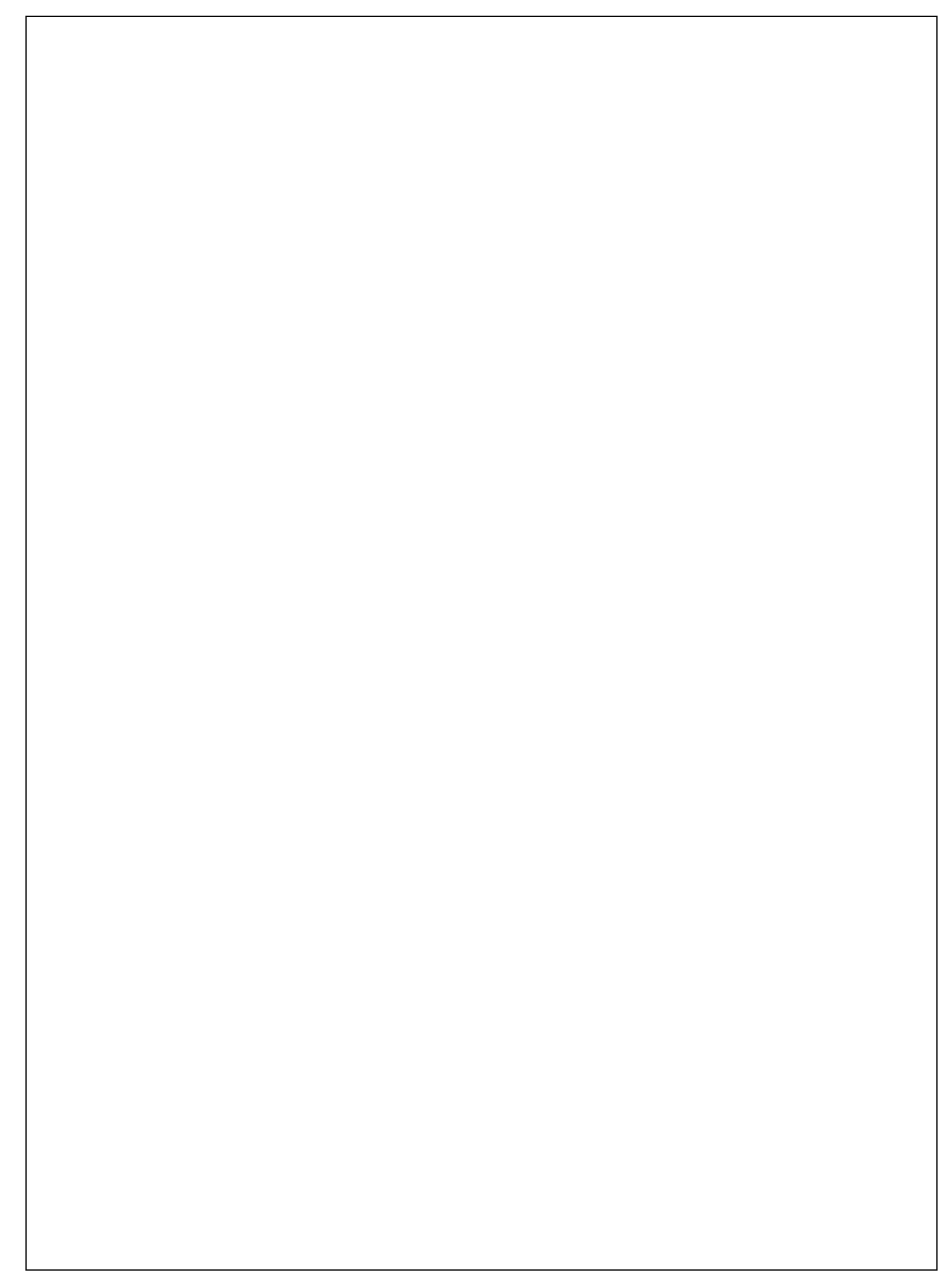

